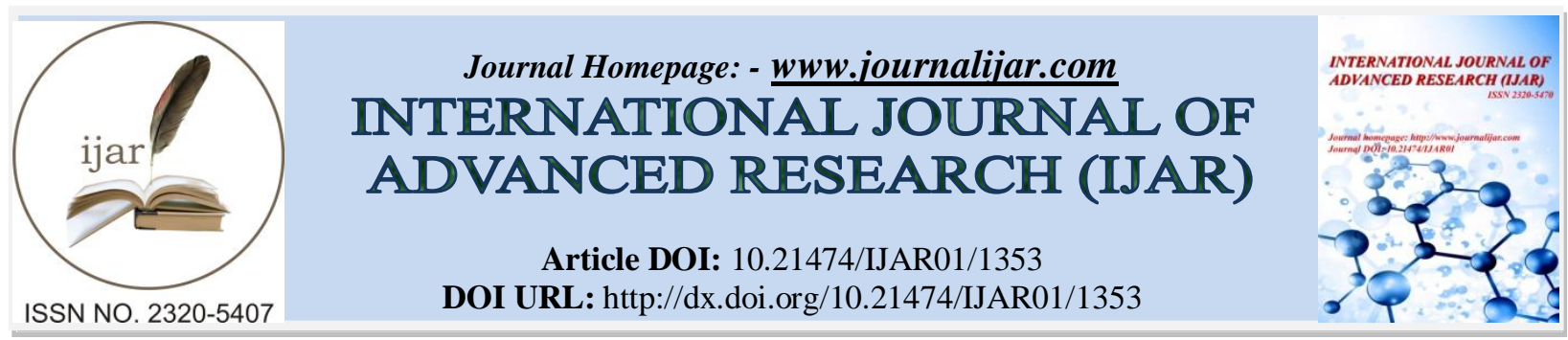

RESEARCH ARTICLE

\title{
SEASONAL DYNAMICS OF Thrips tabaci (Lindeman) AND THEIR CORRELATION WITH WEATHER PARAMETERS ON TRANSGENIC BT COTTON.
}

\author{
Rajesh Soni and Dhakad N.K. \\ Department of Life Science, Devi Ahilya Vishwavidyalaya, Indore (MP), India.
}

\section{Manuscript Info}

Manuscript History

Received: 12 June 2016

Final Accepted: 22 July 2016

Published: August 2016

Key words:-

Incidence, Thrips, population, boll

development stage, correlation

\section{Abstract}

The first incidence of cotton thrips noted during mid July and peak activity during first fortnight of October when crop was in boll development stage. The population remains fluctuated and active throughout crop season. Maximum temperature exhibited significant positive correlation $(r=0.434)$ during first year and non significant positive correlation $(r=0.200)$ during second year while rainfall expressed significant negative correlation $(\mathrm{r}=-0.485)$ during first year and non significant negative correlation $(r=-0.318)$ during second year.

Copy Right, IJAR, 2016,. All rights reserved.

\section{Introduction:-}

Cotton is important commercial crop grown under diverse agro-climatic conditions around the world and vulnerable to attacked from several insect pests. In India with the introduction and successful implementation of transgenic $\mathrm{Bt}$ cotton not only solved the problem of bollworm complex but also cut down the number of insecticidal spray which probably leads sever incidence of sucking pest and occupied major pest status and cause considerable damage in traditional and Bt cotton in India at present. Among the cotton sucking pest, Thrips tabaci (Lindeman) is most important sucking pest of cotton (Wilson \& Bauer, 1993) and known to damage young cotton seedlings, flowers and stems. Different weather factors found to have positive association with thrips population (Li et al., 1992) for their development and seasonal incidence. The knowledge about incidence of pest during cropping season and its possible dynamics helps in designing pest management strategies (Santhosh et al., 2009) hence present study on population dynamics of cotton thrips was undertaken during Kharif seasons of 2011 and 2012 to fulfill the objectives.

\section{Materials and Methods:-}

The experiment was conducted in farmer's field near major cotton growing area of Khargone, Madhya Pradesh, India, during 2011 and 2012 cotton growing season. Single cotton hybrid Brahma BG II was grown in 300 sq meter $(25 \mathrm{~m} \mathrm{x} 12 \mathrm{~m})$ at spacing of $120 \times 45 \mathrm{~cm}$ in isolated plot on $16^{\text {th }}$ June on first year and $11^{\text {th }}$ June during second year and applied 120:60:60 kg NPK/ha. The number of thrips were recorded from (six quadrates, $2.5 \mathrm{~m} \mathrm{x} 2.5 \mathrm{~m}$ and from each quadrants five plants) three leaves (top, middle and bottom). The weekly weather parameters obtained from Zonal Agriculture Research Station, Khargone, Madhya Pradesh, India and correlation coefficient work out between thrips population and weather parameters.

\section{Result and Discussion:-}

The first incidence of thrips started with 1.97 thrips/3 leaves in $29^{\text {th }}$ MSW in the year 2011 and 1.10 thrips/3 leaves in $27^{\text {th }}$ MSW in 2012 when crop was in two to four true leave stage (Table 1). The thrips population reached its peak 
28.22 thrips/ 3 leaves in $41^{\text {st }}$ MSW in first year and 18.31 thrips $/ 3$ leaves in $40^{\text {th }}$ MSW in second year when crop was in boll development stage and all plants parts were present. The population reached lowest level 1.70 insects $/ 3$ leaves in previous year and 1.50 insects/3 leaves in consecutive year in $52^{\text {nd }}$ MSW when crop was almost maturation stage. During both years, thrips population noted fluctuating and remained throughout crop season. Gupta et al., (1997) and Panickar and Patel (2001) also reported peak population of thrips on cotton during the second fortnight of August and first fortnight of October. The present study faintly matches with the results of Khan and Ullah (1994) who reported the peak activity of Thrips tabaci on cotton in August and September. Soujanya et al., (2010) reported the peak incidence of thrips on $35^{\text {th }}$ to $37^{\text {th }}$ standard week.

The correlation studies of both the years revealed that maximum temperature exhibited significant positive correlation $(r=0.434)$ in first year and non significant positive correlation $(r=0.200)$ during second year of the experiment (Table 2). Minimum temperature, morning and evening humidity showed non significant positive correlation while wind velocity showed non significant negative correlation during both years. Rainfall expressed significant negative correlation $\left(r=-0.485^{*}\right)$ during first year and non significant negative correlation $(r=-0.318)$ during second year. Shivanna et al., (2009) reported that maximum temperature was positively correlated with thrips population. Soujanya et al., (2010) and Shahid et al., (2012) reported that thrips population showed significant positive correlation with maximum temperature, minimum temperature, evening relative humidity and rainfall.

Table 1;- Population dynamics of thrips during Kharif 2011 and 2012.

\begin{tabular}{|c|c|c|c|c|}
\hline \multirow[t]{2}{*}{ DAS } & \multirow[t]{2}{*}{ MSW } & \multirow[t]{2}{*}{ Period } & \multicolumn{2}{|c|}{$\begin{array}{c}\text { Thrips/3 Leaves } \\
\end{array}$} \\
\hline & & & Year 2011 & Year 2012 \\
\hline 20 & 27 & 2-8 July & 0.00 & 1.10 \\
\hline 27 & 28 & 9-15 July & 0.00 & 2.12 \\
\hline 34 & 29 & 16-22 July & 1.97 & 2.20 \\
\hline 41 & 30 & 23-29 July & 1.31 & 0.50 \\
\hline 48 & 31 & 30 July-5 Aug & 3.10 & 5.50 \\
\hline 55 & 32 & 6-12 Aug & 4.13 & 5.11 \\
\hline 62 & 33 & 13-19 Aug & 5.25 & 4.79 \\
\hline 69 & 34 & 20-26 Aug & 3.80 & 4.15 \\
\hline 76 & 35 & 27 Aug-2 Sept & 12.30 & 3.11 \\
\hline 83 & 36 & 3-9 Sept. & 14.40 & 2.25 \\
\hline 90 & 37 & 10-16 Sept & 15.11 & 9.95 \\
\hline 97 & 38 & 17-23 Sept & 19.10 & 10.86 \\
\hline 104 & 39 & 24-30 Sept & 21.00 & 12.23 \\
\hline 111 & 40 & $1-7$ Oct & 24.30 & 18.31 \\
\hline 118 & 41 & $8-14$ Oct & 28.22 & 13.76 \\
\hline 125 & 42 & $15-21 \mathrm{Oct}$ & 16.32 & 8.57 \\
\hline 132 & 43 & $22-28$ Oct & 13.25 & 6.88 \\
\hline 139 & 44 & 29 Oct-4 Nov & 10.41 & 6.51 \\
\hline 146 & 45 & $5-11$ Nov & 12.21 & 6.25 \\
\hline 153 & 46 & 12-18 Nov & 7.10 & 4.88 \\
\hline 160 & 47 & 19-25 Nov & 5.51 & 3.32 \\
\hline 167 & 48 & 26 Nov-2 Dec & 4.10 & 3.87 \\
\hline 174 & 49 & 3-9 Dec & 2.63 & 2.58 \\
\hline 181 & 50 & 11-16 Dec & 2.97 & 2.35 \\
\hline 188 & 51 & 17-23 Dec & 2.19 & 1.11 \\
\hline 195 & 52 & 24-31 Dec & 1.70 & 1.50 \\
\hline
\end{tabular}

DAS (Days After Sowing), MSW (Metrological Standard Week) 
Table 2:- Correlation coefficient between thrips population and weathers parameters.

\begin{tabular}{|l|l|l|}
\hline Weather parameters & Year 2011 & Year 2012 \\
\hline Maximum temperature $\left({ }^{0} \mathrm{c}\right)$ & $0.434^{*}$ & 0.200 \\
\hline Minimum temperature $\left({ }^{0} \mathrm{c}\right)$ & 0.118 & 0.127 \\
\hline Morning Humidity \% & 0.193 & 0.140 \\
\hline Evening Humidity \% & 0.200 & 0.128 \\
\hline Rainfall $(\mathrm{mm})$ & $-0.485^{*}$ & -0.318 \\
\hline Wind velocity $(\mathrm{km} / \mathrm{h})$ & -0.047 & -0.124 \\
\hline
\end{tabular}

*Significant at $5 \%$ level

\section{Acknowledgement:-}

Author is highly thankful to zonal agriculture research station, Khargone, Madhya Pradesh, India for providing necessary weather data.

\section{References:-}

1. Gupta, G.P., Agnihotri, N.P., Sharma, K. and Gajbhiye, V.T. (1997): Bio efficacy and residue of imidacloprid in cotton. Pesticide Res. J., 10(2): 149.

2. Khan, S.M. and Ullah, Z. (1994): Population dynamics of insect pests of cotton in dera ismail khan. Sarhad J. Agric., 10(3):285-290.

3. Li, J.Z., Zang, H.J. and Zhang, Z.M. (1992): Observation on the time and spatial dynamics of the diurnal cycle of tobacco thrips. China J. Entomol., 18: 26-30

4. Panickar, B.K. and Patel, J.R. (2001): Population dynamics of different species of thrips on chilli, cotton and pigeonpea. Indian J. Ent., 63(2):170-175.

5. Santhosh, B.M., Patil, S.B., Udikeri, S.S., Awaknavar, J.S. and Katageri, I.S. (2009): Impact of Bt cotton on pink bollworm, Pectinophora gossypiella (Saunders) infestation. Karnataka J. Agric. sci., 22(2): 322-326.

6. Shahid, M.R., Farooq, J., Mahmood, A., Ilahi, F., Ria, M., Shakeel, A., Petrescu-Mag, I.V. and Farooq, A. (2012): Seasonal occurrence of sucking insect pest in cotton ecosystem of Punjab, Pakistan. Advances in Agriculture \& Botanics, 4(1):26-30.

7. Shivanna, B.K., Nagaraja, D. N., Manjunatha, M. and Naik, M. I. (2009): Seasonal incidence of sucking pests on transgenic Bt cotton and correlation with weather factors. Karnataka J. Agric. Sci., 22(3):666-667.

8. Soujanya, P.L., Prasad, N.V.V.S.D. and Rao, P.A. (2010): Population dynamics of sucking pests and their relation to weather prameters in $B t$, Stacked $B t$ and non $B t$ cotton hybrids. Trends in Biosciences,3(1):15-18.

9. Wilson, L.J. and Morton, L.K. (1993): Spider mites (Acari: Tetranychidae) affect yield and fiber quality of cotton. Econ. Entomol., 86: 566-85. 